\title{
Erratum to: Entry of large nanoparticles into cells aided by nanoscale mechanical stimulation
}

\author{
Ramanathan Vaidyanathan · Adam Curtis • \\ Margaret Mullin · Stuart Reid
}

Published online: 5 October 2012

(C) Springer Science+Business Media B.V. 2012

Erratum to: J Nanopart Res (2011) 13:5301-5309 DOI 10.1007/s11051-011-0516-7

This Erratum is to state that Dr Stuart Reid, SUPA, Institute for Gravitational Research, University of Glasgow, contributed as co-author to the paper 'Entry of large nanoparticles into cells aided by nanoscale mechanical stimulation', published in the Journal of Nanoparticle Research Volume 13, Number 10 (2011), 5301-5309. However his name was accidentally missing from the initial author list.

The online version of the original article can be found under doi:10.1007/s11051-011-0516-7.

R. Vaidyanathan · A. Curtis $(\square) \cdot$ M. Mullin

Center for Cell Engineering, University of Glasgow,

Glasgow G12 8QQ, UK

e-mail: A.Curtis@bio.gla.ac.uk

R. Vaidyanathan

e-mail: 0905695P@student.gla.ac.uk

M. Mullin

e-mail: Margaret.mullin@bio.gla.ac.uk

S. Reid

SUPA, Institute for Gravitational Research,

University of Glasgow, Glasgow, UK 